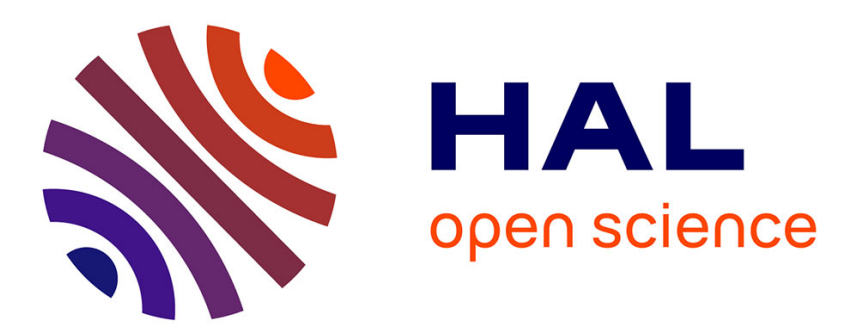

\title{
Institutional Changes: Alternative Theories and Consequences for Institutional Design
}

\author{
Eric Brousseau, Pierre Garrouste, Emmanuel Raynaud
}

\section{To cite this version:}

Eric Brousseau, Pierre Garrouste, Emmanuel Raynaud. Institutional Changes: Alternative Theories and Consequences for Institutional Design. Journal of Economic Behavior and Organization, 2011, 79 (1-2), pp.3. 10.1016/j.jebo.2011.01.024 . peer-01003150

\section{HAL Id: peer-01003150 https://hal.science/peer-01003150}

Submitted on 10 Jun 2014

HAL is a multi-disciplinary open access archive for the deposit and dissemination of scientific research documents, whether they are published or not. The documents may come from teaching and research institutions in France or abroad, or from public or private research centers.
L'archive ouverte pluridisciplinaire HAL, est destinée au dépôt et à la diffusion de documents scientifiques de niveau recherche, publiés ou non, émanant des établissements d'enseignement et de recherche français ou étrangers, des laboratoires publics ou privés. 


\section{Accepted Manuscript}

Title: Institutional Changes: Alternative Theories and Consequences for Institutional Design

Authors: Eric brousseau, Pierre garrouste, Emmanuel raynaud

PII: $\quad$ S0167-2681(11)00055-2

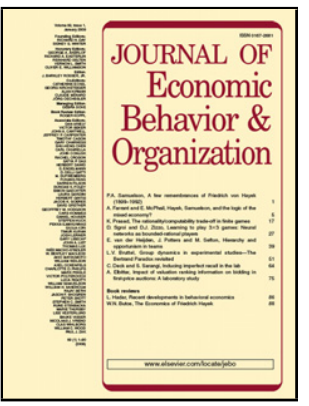

DOI: doi:10.1016/j.jebo.2011.01.024

Reference: $\quad$ JEBO 2693

To appear in: Journal of Economic Behavior \& Organization

Please cite this article as: brousseau, E., garrouste, P., raynaud, E., Institutional Changes: Alternative Theories and Consequences for Institutional Design, Journal of Economic Behavior and Organization (2010), doi:10.1016/j.jebo.2011.01.024

This is a PDF file of an unedited manuscript that has been accepted for publication. As a service to our customers we are providing this early version of the manuscript. The manuscript will undergo copyediting, typesetting, and review of the resulting proof before it is published in its final form. Please note that during the production process errors may be discovered which could affect the content, and all legal disclaimers that apply to the journal pertain. 


\title{
Institutional Changes: Alternative Theories and Consequences for
}

\author{
Institutional Design *
}

\author{
Eric BROUSSEAU \\ EconomiX, Université Paris Ouest \\ EconomiX, Université Paris Ouest, Bâtiment K, Maison Max Weber \\ 200 Avenue de la République, F-92001, Nanterre cedex, France \\ eric@brousseau.info \\ Pierre GARROUSTE \\ Université de Nice - Sophia Antipolis \\ GREDEG \\ 250 rue Albert Einstein \\ 06560 Valbonne cedex \\ pierre.garrouste@orange.fr \\ Emmanuel RAYNAUD \\ INRA SADAPT, Paris \& CES (University of Paris I) \\ INRA SADAPT, 16 rue Claude Bernard \\ 75231, Paris cedex 05, France \\ emmanuel.raynaud@agroparistech.fr
}

This version 16/09/10

\begin{abstract}
:
This paper surveys alternative approaches to the emergence and evolution of institutions. The challenge is to develop frameworks capable of capturing both stability and change. We follow a "descaling" approach to show how founding assumptions about economics-namely, alternative assumptions about individual rationality and the role of social efficiencyinfluence our understanding of the drivers of institutional evolution. We then contrast two families of institutional theory. In the first, institutions are viewed as rules imposed on individuals and the focus is on the strategic games among coalitions that aim to promote or block new rules. In the second, institutions are viewed as shared beliefs; here the idea is to analyze how equilibria that are self-enforcing (in terms of mutual expectations about others' behaviors) can collapse and so induce switching to another equilibrium. Finally, we discuss the political economy literature that examines institutional transitions to a market economy, and we identify long-term drivers as well as short-term political barriers to institutional reforms.
\end{abstract}

Keywords: Rules, Self-Enforcing Equilibrium, Human Rationality, Selection Processes, Political Economy, Institutional Reforms

JEL Code : B 52, D 02, E 02, H 1, 0 43, P 36

\footnotetext{
* We would like to thank Olivier Favereau, Peter Grajzl, Christopher Kingston, Richard Langlois, and Yannick Perez for useful comments on a previous version of this paper. The usual caveats apply.
} 


\section{INTRODUCTION}

The analysis of institutions is a trendy field in economics, as evidenced by the recent wave of books dedicated to this issue that are authored by prominent scholars. ${ }^{1}$ The production of books, rather than articles, suggests that the field has reached a certain level of maturity. However, Dixit (2009) argues that understanding the process of institutional change is still undertheorized, even though policy making today is dominated by the idea that most policies consist of designing institutions. In the context of transition or development-and also of reforms in all kind of policy domains (finance, labor, innovation, competition, etc.) within developed countries - many economists have been involved in processes of institutional design. Yet the implementation of institutional reforms and the control of institutional evolution remain underanalyzed. On what basis do economists advise policy makers? Are there any empirical results to support their recommendations? If growth-enhancing institutions have been identified in a specific country, can other countries learn from and transplant them? Should we change institutional bundles in an incremental way, or should we favor a "big bang” approach? Can institutional change be easily managed?

On the basis of the current state of the literature, we attempt to present the essential challenges contemplated by scholars involved in the economics of institutional change while providing a context for the papers in this special issue. The puzzle is often how to use the same framework to explain both the persistence and evolution of institutions. Alternative frameworks propose different conceptions of institutions that feature contrasting processes of emergence and varying susceptibility to being manipulated by economic agents.

\footnotetext{
${ }^{1}$ Examples include Acemoglu and Johnson (2005), Aoki (2001), Barzel (2002), Bowles (2004), Dixit (2004), Eggertson (2005), Greif (2006), North (2005), North et al. (2009), and Ostrom (2005).
} 
Our paper proposes a “descaling” approach to the literature by examining those contributions that are wider in scope before considering more focused questions. In Section 2 we show how founding assumptions and fundamental conceptions about economics influence analysis of the nature and evolution of institutions. In particular, we focus on alternative conceptions of individual rationality and on the purpose (if any) of social organization. In Section 3, we review and contrast two families of contributions that are specifically dedicated to the analysis of institutions and institutional change. Some scholars envisage institutions as endogenous and evolving beliefs (about the behavior of others) that are embodied in individual mental models. This vision is in clear contrast to the other family of works, which views institutions as exogenous and binding rules that constrain individual actions. In the latter approach the design of rules is clearly strategic, and attention is paid to the tactics used by various agents or coalitions to manipulate (or at least influence) the "rules of the game". This later vision leads to the realm of literature reviewed in Section 4, which considers how interactions among groups-especially between rulers and the governed-influence the process of institutional evolution.

\section{FUNDAMENTAL ASSUMPTIONS AND THEIR CONSEQUENCES}

\section{FOR INSTITUTIONAL CHANGE}

There is an unambiguous consensus that human beings create institutions. However, controversies remain concerning the relationships between individuals' behaviors and institutions as well as what these relationships imply for how institutions are defined and how their evolution is analyzed. Some scholars defend the idea that rational individuals voluntarily and purposely create institutions, whereas others argue that institutions emerge spontaneously-i.e. result of human action but not of human design (Hayek, 1988). Still others combine these views by considering how the drivers of institutional evolution depend 
on the type of institution under scrutiny. For instance, it is often suggested that formal rules are designed whereas informal rules are spontaneous. These differences are linked with fundamental assumptions about economics. We focus on two such assumptions. In Section 2.1, we explore the conception of individuals' preferences and cognitive capacities; in Section 2.2, we examine the extent to which the design and evolution of social systems are a function of their socioeconomic outcomes.

\subsection{Conception of Individuals' Preferences and Cognitive}

\section{Capacities}

The conception one has about individual motivation and ability is one of the most fundamental assumptions for the analysis of economic and social systems. In institutional analysis, the relevant contrast is between analytical approaches based on self-interested behavior (Section 2.1.1) and those that accept the possibility of prosocial behavior (Section 2.1.2). In addition, regardless of which approach is taken, assumptions about the nature of human rationality lead also to contrasting views of the drivers of institutional evolutions.

\subsubsection{Equilibria among Selfish Individuals}

When individuals are presumed to be self-interested optimizers, institutions defined in terms of social rules can be rationalized as the equilibrium outcome of strategic interactions. ${ }^{2}$ In this approach, only an exogenous shock to the set of strategies or their associated payoffs can induce a change of rules. When the equilibrium resulting from individuals' decisions is socially bad, as in the one-shot Prisoners’ Dilemma, no player has an incentive to deviate from the Nash equilibrium. In this case, the only way to alter the equilibrium is by introducing

\footnotetext{
2 As MacAdams and Rasmusen (2007) sum up: “after discussing such diverse convention models as signaling, repeated prisoner's dilemmas, and cascades, we see that much of human behavior that seems to be driven by moral beliefs is actually driven by utility maximization."
} 
a third party (a legislator, judge, or other authority) and granting her the power to change the rules of the game. Any change in institutions is therefore exogenous and cannot occur solely by players’ choices.

If one assumes bounded rationality - in other words, that individuals have selfregarding preferences but are unable to optimize- then institutions are viewed as devices for enabling coordination of behaviors among individuals who follow routines to economize on decision making. The question is: How do these individuals converge toward compatible behaviors? Peyton Young's $(1996,1998)$ seminal contributions rely on evolutionary arguments to explain how regularities of behavior emerge within a population of boundedly rational agents, and characterize some properties of that evolution. In his framework, perturbations can arise endogenously in a given social equilibrium. Change is possible if individuals: (1) can play something other than their best response (by mistake and/or to experiment); (2) are unable to remember all the past plays; and (3) do not consider the entire population playing the game, but rather a subset of it (e.g., their "neighbors”), as the reference for their decision. In these circumstances, Young's results show that the evolution of social institutions is characterized by long periods of stability punctuated by infrequent but large changes (depending on the three parameters just listed). ${ }^{3}$

Another attempt at integrating bounded rationality into the evolution of institutions is provided by Aoki (2001, 2011). In this work, limited rationality means that agents have neither a complete knowledge of the rules of the game nor the ability to make perfect inferences about other agents' strategic choices. Hence agents form what Aoki calls "subjective game models” of the structure of the game they play. Thus institutions consist of

\footnotetext{
3 This dynamic is often referred to as "punctuated equilibrium”, a concept from evolutionary biology that was initiated by Eldredge and Gould (1972). Equilibria are either stable, irreversible, or irrevocable. An equilibrium is irreversible if it is possible to go from a final state back to the initial state but not by the reverse path. An equilibrium is irrevocable if it is no longer possible to go from a final state back to any previous state.
} 
the shared perceptions that link individuals' truncated beliefs systems about the game they play, summarizing salient aspects of the equilibrium and facilitating coordination (this view is shared by Sugden, 2011). Section 3 will develop the consequences of this framework for the analysis of institutional change. For now, we need only observe that the pattern of institutional dynamics is similar to the one envisioned by Young (1996): long periods of stability punctuated by short periods of "institutional turbulence”.

\subsubsection{Prosocial Preferences as Stabilizers and Institutions}

An alternative to the view of human behavior as driven only by selfish motives is to assume that agents have prosocial preferences (altruism, fairness, and other-regarding preferences). The literature on altruism (see, e.g., Gintis et al., 2005) provides evidence of the wide diffusion of such preferences across societies (whether groups of apes, human "archaic" tribes, or modern societies). The problem is to explain how these preferences affect the emergence and evolution of institutions. Two main links can be established between the literature on prosocial preferences and the analysis of institutional dynamics. First, if one focuses on the impact of individual preferences, then prosocial preferences seem to reinforce institutional stability. Second, if scholars analyze the origin of prosocial preferences, then the universes of perfect versus bounded rationality must be contrasted in order to understand the patterns and stability of institutional evolution. ${ }^{4}$

\footnotetext{
${ }^{4}$ As will be emphasized in what follows, focusing on the existence of prosocial or other-regarding preferences raises the issues of (i) the endogeity of these preferences and (ii) a possible hierarchy among human institutions (since it may be that superior "human" values and norms themselves are interpreted as fundamental institutions shaping the design and the performance of more easily identifiable and manipulable institutions, such as formal ones). However, this does not lead to systematic departure from a rational choice approach to institutions because prosocial preferences could easily result from explainable choices or selection processes. Nor does it lead to grounds for a value judgment regarding the relative desirability of prosocial versus self-regarding preferences. As pointed out by Adam Smith, individual motivations need not be connected to social ends.
} 


\subsubsection{Prosocial Motivation and Institutional Stability}

First, prosocial behaviors may reinforce compliance with collective rules. In this case, institutions are less challenged and therefore more stable than in the case of purely selfish individuals. Fehr and Fischbacher show experimentally that individuals are strong reciprocators (and not only conditional ones), and they point out (2005, p. 152) "that, by changing the incentives for selfish types, strong reciprocity affects the prevailing interaction patterns and the constraints on individual behavior, that is, the prevailing contracts and institutions." 5 The notion of "intervenor” introduced by Hurwicz (2008) is another attempt to explore the issue of compliance in relation to individual social preferences. ${ }^{6}$ Under this scenario, "guarantors" of the rules emerge spontaneously in the society and encourage compliance.

More generally, Greif (2006) explores how compliance is due to the complex combination of formal enforcement, social pressure, and self-motivation, with the latter two phenomena possibly linked to prosocial motivations. In a similar spirit, Binmore (2010) insists that formal institutions must fit in with the more fundamental principles structuring human interactions, which are related to a general principle of fairness (more on this in the next section). Thus, some "higher-level” institutions constrain the games according to which "lower-level” institutions are designed. This stream of literature analyzes the complex web of factors explaining the stability of the institutional framework and in this sense contributes to analysis of the interplay between insitutions and human behavior.

\footnotetext{
${ }^{5}$ Strong reciprocity in this literature combines the altruistic reward of cooperative behavior with the propensity to punish (at personal cost) those who violate social norms.

${ }^{6}$ According to Hurwicz (2008, p. 287): “There may be guardians (individual or collective) who are in sympathy with the rules, for instance, whose ethical standards rule out corrupt behavior. Such persons or groups, whom we will call intervenors (that's my own term-I don't think anybody else uses it), may have the ability (through power, financial assets, personal charisma, or status combined with the population's respect), as well as the inclination, to discourage improper behavior of lower-level guardians.”
} 


\subsubsection{The Origin and Stability of Prosocial Motivations}

Because prosocial preferences may affect compliance with institutions, scholars have an interest in understanding their origin. This leads them to view such preferences as (fundamental) institutions because they can be interpreted as rules endogeneized by individuals. Analyzing the emergence and stability of these rules therefore contributes to our understanding of institutional dynamics. Again there are two possible routes: either individual preferences reflect selfish choices that do, nonetheless, incorporate feedback regarding the satisfaction of others; or individual preferences reflect selection processes that result in “endogenization” of the collective by individuals. Let us review these possibilities in turn.

For the case of "selfish" prosocial behavior, one can argue that prosocial behaviors are rational. This is the path explored by Bénabou and Tirole (2006), who show how an extended set of motives explains deviation in behavior from the standard homo economicus model. Human beings are driven not only by extrinsic motivation, such as rewards and reputation, but also by intrinsic motivations. However, as exemplified by the fact that altruism may simply serve to improve the individual's self-image (a concept qualified of "warm glow" effect), the assumption remains that human action is grounded in a self-regarding cost-benefit analysis that includes a wider set of components, in particular, the hedonic value of self-esteem and the value of compliance with social norms that can be considered as collective assets empowering inviduals (see Bénabou and Tirole, 2007). In the end, a set of “external” constraints grounded in the social game explains why a self-regarding optimizer takes others into account when choosing an action. As a corollary, the resulting prosocial behaviors are reversible (and 
exogeneous) since they depend on the set of collective constraints to which agents are submitted. ${ }^{7}$

In contrast to the explanation based on explicit, self-interested calculation, prosocial behaviors can be explained by an alternative logic of reciprocity. Two principal directions have been explored, both of which rely on evolutionary micro foundations to explain the prevalence of these behaviors. Some scholars consider prosocial (other-regarding) preferences as a selected predisposition rooted in human behavior (see, e.g., Gintis et al., 2005). People in a given community (a family, a village, a nation) have internalized social standards such as reciprocity or other-regarding preferences. This approach could still be called "preference based" in the sense that social preferences are arguments in the individual's utility function. The propensity to cooperate is, in a sense, a genetic pattern of behavior that has been selected for throughout human history. ${ }^{8}$ Other scholars believe that social norms result from a process of selecting not particular types of preference but rather particular patterns of behavior in a repeated coordination situation. This approach, which is well illustrated by Binmore (2010), can be called "belief based” because prosocial behaviors are defined as Nash equilibria that rely heavily on individual beliefs about how others will act in a particular circumstance. Social preferences result from a solution (e.g., sharing food among nonrelated agents)

\footnotetext{
7 One of the main motivations of the Bénabou and Tirole (2006) paper is digging deeper into the complementarity and substitutability effects among material rewards (or punishment), social reputation effects, and self-esteem motivations in order to explain individual contributions to public goods, cooperative attitudes, and prosocial behaviors more generally. Given the combination of specific individual motivations and social settings, spontaneous deviations from the socially optimal contributions can be identified. In some cases, an adequate manipulation of incentives can affect social welfare. So in this paper, individual preferences and collective feedback on individual behavior are both exogenous. In their working paper (Bénabou and Tirole, 2007), the authors attempt to endogeneize individual and collective beliefs and to explain thereby how individual preferences and collective constraints on them emerge (essentially on a functional basis). Their main insight in this paper is that beliefs can be built to protect investments in assets whose value is uncertain. This could have either positive or negative effects on welfare, because norms and taboos may divert from (individually and collectively) optimal levels of investment or effort by making it difficult to assess rationally the opportunity cost of efforts.

${ }^{8}$ Camerer (2003) demonstrates the neurobiological basis of such behavior. This approach is not far from the one developed by evolutionary psychologists.
} 
discovered at some time in history and then replicated thereafter because it is satisfactory and efficient. For instance, fairness in Binmore's framework is the solution of the "game of life". Relying upon the folk theorem, he demonstrates that fairness is a socially self-enforced rule of conduct. $^{9}$

Both approaches are attempts to endogenize the emergence and stability of the most fundamental human institution: the "natural” propensity to cooperate and consider oneself as a member of a group. However, they view the stability of cooperation from much different perspectives. In the preference-based approach, the cooperative equilibrium is irrevocable (see footnote 3) because all agents eventually develop preference functions that differ from those of individuals at the society's origin. In the belief-based approach, however, preference functions remain fairly constant throughout the history of humans: what evolved mostly were beliefs about the behavior of others. It should therefore be possible to switch back to the initial state of equilibrium, which may explain the collapse of the "social contract" in circumstances such as civil war.

These two approaches lead to a much more stable cooperative equilibrium than the one envisioned by a purely calculative reciprocity approach à la Benabou and Tirole. Indeed, in this latter approach the variation in formal institutional frameworks may change individual incentives to reciprocate or to comply, since individuals compute and balance the hedonic payoff of variations in their individual wealth, social reputation, and status while taking into account signaling and self-esteem (dignity, identity) concerns. In the Binmore and Gintis approaches, endogeneously developed routines dominate calculus: although behaviors can

\footnotetext{
${ }^{9}$ The stability of such an equilibrium is subject to debate. Imagine a population of altruists in an equilibrium into which you introduce selfish mutants. Some scholars claim that the equilibrium is unstable because the selfish mutants could take over the population of altruists. However, others show that, in a "viscous" population (i.e., once without imposed subdivisions but also with limited dispersal), altruists can not only resist the invasion of selfish mutants but can also take over such a population (see Van Baalen and Rand, 1998).
} 
change, they are less sensitive to external incentives. To put this another way, we again identify a contrast between theories that view (even informal) institutions as unstable because the equilibria they embody can easily be challenged by individuals' strategies and, on the other hand, theories that consider institutions as being immune to individual behaviorseither because changing strategies leads to coordination dilemmas or because individuals are less than entirely strategic owing to their procedural rationality and their "satisficing" (rather than maximizing) behavior.

Because North and his colleagues do not deal explicitly with the issue of prosocial convention, their view of institutional stability as anchored in human beliefs is an approach intermediate between that of Benabou-Tirole and Binmore-Gintis (see, e.g., Denzau and North, 1994; Mantzavinos et al., 2004). Their theory is based on recognizing the potentially higher payoffs to innovators and shirkers while simultaneously considering the risks (of a negative outcome) that they bear. Individuals therefore oscillate between preferences for conformity, which favors collective action and security, and preferences for rule breaking, which favors innovation. ${ }^{10}$

\subsection{Institutional Purposes and Outcomes}

Most would agree with Hayek’s statement that the task of economic theory is to explain how an overall economic order is achieved that coordinates a large number of individuals. Institutions play a central role in this inquiry because they provide society's members with alternative solutions for coordinating the uses of economic resources. This is why economists

\footnotetext{
${ }^{10}$ These considerations lead to a theory of the emergence of formal and informal institutions. Individuals are characterized by their specific mental models that enable collective choices and interactions. Local interactions (within organizations such as families, schools, or firms) make these mental models progressively more similar and shared. When mental models are shared by all the members of an important population, informal rules develop. Even if (informal) institutions are intrinsically stable because they are anchored in mental models, they can be ruined by free riding. Free-riding behavior increases with population size, and agencies (rulers) are needed to enforce the rules-hence the necessity of (rationally built) formal institutions.
} 
view institutions as factors that influence the production of wealth and thus consider their impact from a productivity perspective. In the short run, an issue is how best to assess the impact that institutions have on other factors of production —in particular, on human capital. In the long run, we consider the dynamic of accumulation and development. But this does not mean that the quest for economic efficiency is the main driver of institutional evolution. Indeed, institutions can affect economic efficiency even as they evolve according to other drivers. To disentangle the economic effects of institutions from the analysis of what drives their evolution, we consider successively two perspectives. First, in Section 2.2.1 we adopt the perspective according to which institutions are the result of intended human action and then examine the criteria by which this action can be based and/or assessed. Second, in Section 2.2.2 we adopt the perspective according to which institutions are the unintended consequence of human action; here institutions are viewed as resulting from a process of evolution, and economists analyze the criteria by which they are selected.

\subsubsection{The Motivations of Human Action toward Institutions}

When institutions are considered as the result of human intentions, it is worth considering the motivations that affect their design. This approach is useful for two reasons. First, from a normative point of view, economic efficiency can be one of the criteria used to assess the social desirability of alternative institutions or institutional reforms. Second, from a positive perspective, criteria of efficiency are often relied upon by decision makers to benchmark alternative institutional designs when attempting to influence institutional evolution. However, other factors — in particular, distributional issues—might also explain motivations for, as well as the balance of forces in, institutional evolutions.

Although Pareto optimality is the "natural” theoretical criterion relied upon to analyze institutional change and choices, the criterion of economic growth has been heavily used in 
most empirical contributions. In what follows we comment on the logic of these two criteria, so central in institutional analysis, before discussing the biases they may induce as we examine institutional dynamics.

Pareto optimality is often used to identify mechanisms that facilitate convergence toward a more desirable situation. Not only does this concept allow us to (partially) rank alternative institutional solutions, it also enables us to compute the Hicks-Kaldor compensation required to switch from one situation to another. ${ }^{11}$ Furthermore, Pareto reasoning justifies the intervention of a (benevolent and costless) external entity if spontaneous equilibria prove to be suboptimal. It thus appears that the Pareto criterion is an essential tool for analyzing institutional policies_-provided an adequate design can guarantee the social planner's benevolence-because this criterion justifies the planner's role and provides a basis on which its decisions can be grounded.

Despite its theoretically appealing properties, the Pareto criterion runs into several difficulties when called upon to analyze or decide upon institutional changes. In practice, comparing regimes in terms of Pareto efficiency is a complex procedure when large communities are involved. And even in theory, if multiple nonrankable Pareto-enhancing institutional alternatives are identified then there is no objective way to choose one distribution of wealth over others. Thus, by choosing one equilibrium, a social planner decides who will get more and who less-given that the resulting (Nash) equilibrium will exhibit neither evolution nor spontaneous compensation between individuals. This fact might justify compensation organized by the authority, but it would not be Pareto improving and thus not legitimate in terms of the considered framework. More sophisticated criteria (such as

\footnotetext{
${ }^{11}$ As explained in Section 4, failures to credibly commit to manage such compensations can explain collective preferences for the status quo.
} 
those proposed by Sen, Rawls, and others) could then be mobilized. However, the Pareto criterion is clearly not up to the task of either deciding or managing institutional evolution.

Another limit of the Pareto criterion is highlighted by Demsetz (1969), who points out that the implementation constraints of Pareto-enhancing "solutions" are usually neglected. This leads Williamson (2000) to propose what he calls the "remediability" criterion, according to which a prevailing social arrangement is presumed to be efficient unless a feasible alternative arrangement can be described and implemented with expected net gains.

More generally, one of the problems raised by the Pareto optimality criterion is that it is fundamentally static whereas institutions exist in a changing and uncertain world. Given our inability to assess accurately the future dynamic outcomes of alternative institutional solutions, it's possible that the Pareto-enhancing solutions identified at one particular moment would not be enhancing under alternative circumstances. Institutions that are "second best" for a wide range of parameters could thus perform fairly well in general without satisfying Pareto preference criteria. Therefore, from a dynamic perspective, it might be better to evaluate an institution's "adaptive efficiency" (as suggested by North) than its Pareto optimality. This would imply taking into consideration such factors as learning capabilities, the ability to minimize switching costs, the likelihood of innovation, resilience, and so forth. ${ }^{12}$ Yet in the current state of our knowledge, these dynamic capabilities of institutional frameworks have not been operationalized.

\footnotetext{
12 This is why, beyond Pareto efficiency or growth (see next paragraph), several economists rely on a number of other, often less quantifiable criteria either to evaluate the quality of institutions or to assess some of their purposes. Many of these criteria are of an "evolutionary” nature. For instance, Posner (1973 emphasizes adaptability when he claims that Common Law tends to be superior to Civil Law because the former adapts more rapidly in coherence with the evolution of economic and societal issues and practices (but see the discussion of this claim in Section 4.1 to follow). Mantzavinos et al. (2004) argue for the use and transmission of knowledgeenhancing learning and adaptation. Greif and Kingston (2010) discuss the difficulty of identifying criteria of institutional performance that are analytically satisfying and empirically implementable.
} 
In addition to Pareto optimality, economic growth has been one of the most "obvious" criteria used to appraise the efficiency of institutions. This criterion combines several advantages. First, statistics on economic growth are available for a large range of jurisdictions and on significant periods of time. Second, this criterion mostly concerns the "size of the pie" and is unhampered by the distribution issue-although this is a drawback when we seek to understand how motivations affect institutional evolution in a positive perspective (see Section 4). There is general agreement among economists on the fundamental importance of institutions in explaining differences in growth among countries (see, e.g., Rodrik et al., 2004), but understanding the causal factors behind the observed correlation remains a challenge. One key reason is that economic activity is simultaneously influenced by a bundle of different institutions. Some authors attempt to mitigate this problem by disentangling the various institutional components and then measuring the contributions of each (e.g., Acemoglu and Johnson, 2005). Others "neutralize" these systemic effects by focusing on the impact of specific institutions; a good example is the somewhat controversial contribution of Shleifer (and various co-authors) linking different legal regimes to specific economic outcomes, as summarized in La Porta et al. (2008). ${ }^{13}$ All these works raise fundamental

13 Shleifer, La Porta, Djankov, and their co-authors initiated the literature on legal origin that, in essence, establishes a causal relationship between the logic of the law-which is presumed to determine the margins of adaptability and innovation of the private actors and hence the likelihood of the government intervening in and regulating the economy - and growth. The transmission mechanisms highlighted by these authors are the ability to create and fund corporations (and thus the ease of establishing a business) and the level of development of financial markets. However, much controversy exists concerning the analytical inferences on which these assumptions are built as well as the way they are "empirically proven".

Many analytical arguments have been made in favor of Common Law as against Civil Law, but it remains to establish whether the apparent superior efficiency of Anglo-Saxon types of socioeconomic regulation is due to the identified formal aspects of these types or if these aspects simply reflect more fundamental underlying factors that favor growth. Comparative legal analysis generally focuses on specific mechanisms (e.g., Posner on dynamic adaptability of the case law, La Porta and others on the protection of minority shareholders, Djankov and colleagues on the ease of establishing a business), and alternative designs can be benchmarked with respect to a particular issue. However, this does not automatically allow comparisons among systems in which they are implemented. The reason is that, since institutional complementarities matter, it is necessary to compare also the other institutional components and their interplay. Hence the transmission mechanisms between local microeconomic effects and macro properties of the economy are usually ignored and are seldom discussed or seriously analyzed. Moreover, the literature on legal transplants (see Berkowitz et al., 2003) underscores that it is 
issues. In particular, the attempt to unbundle systemic effects into a set of simple and independent impacts goes against the idea of institutional complementarities that is advocated by many scholars (see Aoki, 2001). Moreover, the theory of how microeconomic effects on individual behaviors are related to macroeconomic outcomes remains obscure with respect to several issues. It also runs the risk of suggesting that there is only one (or a single set of) "best practice(s)" that is applicable everywhere-and should be the target of institutional reforms (Rodrik, 2008)—even though the context of implementation (just like the most fundamental characteristics of customs and the social contract) matters a great deal.

The economics of institutions is largely based on analysis that assumes the search for efficiency is an essential driver of evolution or at least a justification for reforms. However, the efficiency criteria to be considered-as well as the complex causal relationship between the considered performances and the relevant institutional characteristics-remain open research questions. Our present state of knowledge consists of an accumulation of works that are far from forming a fully consistent and mature body of evidence. Among the reasons for this shortcoming are certainly still incomplete analyses of the complex processes of building

not so much the origin of the law adopted (i.e., its legal family) that matters as how the country adopted the law (internal development versus transplantation). This reinforces the notion that attention should be paid to institutional complementarities — in particular, between the formal law, the polity, and the informal institutions of a society. In many cases the superiority of Common Law is also debated. For example, several scholars (see, e.g., Arruñada and Garoupa, 2005; Deffains and Kirat, 2001) have suggested that several legal institutions in operations in various countries of civil law tradition are more efficient than English or U.S. ones (and vice-versa, of course), and others (e.g., Hadfield, 2008) argue that placing the legal families in opposition is pointless.

From an empirical standpoint, the comparative evidence regarding growth and legal regime is rife with shortcomings. These range from fundamental criticisms - for instance, are there not hidden social costs of performance measured in terms of growth? - to errors and biases in the way institutions are characterized. With regard to the latter issue, some authors highlight that many countries switch among legal regimes (Guerriero, 2010; Hayo and Voigt, 2010). Others point out the difficulties associated with measuring key variables as well as the excessive reliance on experts, whose opinion can be biased. (Note that many seemingly composite indicators provided by some organizations rely on assessments provided by other organizations that rely themselves on the same indexes, thereby reinforcing instead of correcting their biases.) From the viewpoint of econometrics, it is not certain that any macroeconomic effects can be proven because the (hidden) transmission mechanisms cannot be tested and because it's unlikely that all relevant control variables have been included in the regressions. Yet methods continue to evolve, especially on the basis of the "natural experiment" methodology (e.g., Guerriero, 2010). The problem is to identify a sufficient number of convincing natural institutional experiments with clear transmission effects. In their absence, the only useful information is that derived from historical narratives (as pointed out by Greif and Kingston, 2010). 
collective preferences within human societies and of the interplay between the many collective mechanisms that frame individual behaviors, preferences, and their dynamics.

\subsubsection{Institutions as the Result of Processes of Selection}

Many scholars adhere to the view that a process of selection drives institutional change, but there is some debate over whether this process converges to an efficient solution. On the one hand, contributions rooted in the "Austrian” approach suggest that it does. For instance, some scholars have looked at the evolution of Common Law as the result of an effort, conscious or not, to induce more efficient outcomes. This so-called efficiency hypothesis was first formulated by Posner (1973) in the spirit of Alchian (1950). Efficient rules are less likely to be challenged by agents and more likely to survive (Priest, 1977). They might also benefit from gradual improvement, as occurs in the evolution of laws though precedents (see DariMattiaci et al., 2011, for a model that captures the cyclical dynamic of such a process).

On the other hand, the analysis of selection processes-whether in economics or biology—shows that the survival of some "phenotypes" cannot be simply attributed to their intrinsic and superior quality (see, e.g., Chiappori, 1984; Hodgson, 1994, pp. 207-12; Silverberg, 1994, pp. 213-17). The dynamic of populations do not rely only on comparisons among individuals. Moreover, these processes do not guarantee the selection of efficient "genotypes”; since populations (which are selected) are made of set of individuals who themselves are the assembling of wide set of components (genes). In addition, as shown by Pólya’s urn heuristic, ${ }^{14}$ the nonergodic nature that characterizes many "path-dependent" processes allows for different paths to follow from identical initial situations; and these paths

\footnotetext{
${ }^{14}$ Imagine a device filled with two kinds of colored balls. The procedure of Pólya's urn mechanism is that one randomly draws a ball from the urn and then returns the selected ball while adding another ball of the same color (see Pólya, 1957).
} 
do not converge to a unique absorbing state. ${ }^{15}$ Even when different paths do converge to a unique state, nothing guarantees that this state is optimal. The victory of one type over another may actually be best explained by the relative size of their populations. As is well illustrated by competition among technological standards, the standard (subpopulation) with the largest “market share” may well overwhelm the others (Arthur, 1989; David, 1985; Geroski, 2000). ${ }^{16}$ Behavioral patterns can also play a role: aggressive or selfish players will overcome pacific or cooperative ones and end up dominating a population (Axelrod, 1986; Ullmann-Margalit, 1978).

It is not difficult to show that the naive incorporation of evolutionary processes into economic analysis misunderstands the lessons to be drawn from biology (Hayek, 1988; Hodgson, 1998). The latter has no criteria of efficiency, as the biology of evolution relies on the notion of fitness. ${ }^{17}$ The ability to survive may be a factor explaining evolutionary processes. It is hardly a scientific (or moral) criterion of normative assessment. More fundamentally, the notion of efficiency is endogenous in social systems. It depends not on the constraints of Nature but rather on the preferences of agents, so institutional systems endogenously create their own criteria of efficiency as well as their own processes of selection (see Brousseau, 2000). ${ }^{18}$

Thus, nothing guarantees that social systems will evolve toward increased efficiency, however that is defined. Furthermore, most research on the processes of selection among

\footnotetext{
${ }^{15}$ A process is nonergodic if there is any possibility that it could follow different trajectories from the same initial position.

${ }^{16}$ In the case of competition among technologies, the victory of less efficient standards is highly debated. See in particular the work of Liebowitz and Margolis (1994, 1995), who discuss the notion of sociotechnical efficiency and the role of sponsors who strategically shape a technology and its diffusion. The work of Brousseau and Raynaud (2011) may be viewed as an application of these ideas to the analysis of competition among institutions.

${ }^{17}$ In evolutionary biology, "fitness” is the reproductive capability of a certain genotype's members.

${ }^{18}$ For instance, that investors withdraw money from less profitable ventures to reinvest it in more promising ones is a function of many conventions regarding what is "right" and how performance should be assessed.
} 
institutions confirms that agents are unlikely to anticipate the results; the processes of institutional evolution are nonergodic, so it is extremely difficult for individuals to develop strategies that would guarantee any particular outcome. We must therefore recognize that competitive selection among institutional solutions does not systematically eliminate costly governance structures, that agents can make wrong choices, and that the rationality of agents is "situated" and functions within their information environment (which includes their specific past experiences, their stock of knowledge, etc.). Moreover, observation of surviving institutional patterns — and of the evolutionary paths that led them to emerge and succeedmay not be enough to identify either the "right" institutions or the strategies needed to develop them.

More generally, when analyzing institutional evolution we must face the question of the ends of collective equilibria or organizations. This explains why the literature remains strongly influenced by alternative conceptions of economics and social sciences. It also explains the diversity and lack of consistency of today's contributions.

\section{ALTERNATIVE THEORIES OF INSTITUTIONS AND INSTITUTIONAL CHANGE}

The previous section described how various fundamental assumptions in economics shape our understanding of institutions and institutional evolution. Here we narrow the scope by looking at the different analytical frameworks that have been built to analyze the emergence and dynamics of institutions. Each framework yields an explicit characterization of institutions, and the analysis of institutional change is then derived from this characterization. Recall from the introduction that any theory of institutional change must also explain institutional resilience. We start in Section 3.1 by contrasting alternative definitions and conceptualizations 
of an institution before examining more closely, in Section 3.2, their consequences for the analysis of institutional change.

\subsection{Definitional Issues}

We have illustrated the lack of consensus on defining and characterizing institutions. ${ }^{19}$ Although accepting pluralism is an option, it runs into the problem of confusion among alternative analyses. Organizing the definitional heterogeneity is valuable because it allows us to benefit from a clearer view of the landscape and from a characterization of the main contrasts between different conceptualizations. At the risk of oversimplifying, we can distinguish two principal conceptualizations of institutions, at least within the boundaries of economics (see Hodgson, 2006, for a broader view): institutions as (external) rules versus institutions as repositories of shared beliefs (about each other behaviors). This distinction is well developed elsewhere, so we will be brief in discussing these two branches of thought. (For more detailed descriptions, see Aoki, 2001, Chap. 1; Aoki, 2011; Greif, 2006, Chaps. 1 and 2; Greif and Kingston, 2010; and Kingston and Caballero, 2009.)

Before commencing, we should emphasize that there is not a one-to-one correspondence between each branch of thought and type of institution. A distinction is often made between formal and informal institutions, but in theory at least, both approaches are able to handle both types of institutions. Rules can be crystallized in explicit documents and procedures (e.g., a political constitution) or through social conventions (e.g., the social norm of tipping in a restaurant). Mutual expectations may also be explicitly formalized (driving codes and related enforcement) or may instead rely only on recurrent patterns of behavior based on sociocultural transmission and enforcement. In addition, both approaches must deal

\footnotetext{
${ }^{19}$ Talking about New Institutional Economics, Roland (2004, p. 3) remarked that "there are by now probably as many interpretations of the New Institutional bible as there are different Protestant churches”.
} 
with potentially complex interactions among formal and informal institutions (Dixit, 2004). Indeed, a specific sector might rely on traditional social norms in addition to-or despite the existence of-formal law (see Bernstein, 2001, for a good illustration). Note also that formal institutions may adopt aspects of informal ones. For instance, drawing on Macel Mauss's sociology, Platteau and Sekeris (2010) analyze how self-esteem and reputation affect gift exchange and thus the emergence of power relationships.

\subsubsection{Institutions as Sets of Constraining Rules}

The first branch has its roots in the seminal contribution of North and analyzes institutions as the exogenously given "rules of the game" of a society, the "humanly devised constraints that structure human interactions” (North, 1990). In the short run, agents and organizations (firms, political parties) are all embedded in a set of both formal and informal rules that constrain their behavior. While North and his epigones adopt a positive approach to explaining the nature and stability of extant institutions, other authors who adopt the "institutions as rules" perspective are more normative and view institutions as mechanisms designed by a (benevolent) “social planner” (Hurwicz, 1994; Myerson, 2009). The aim here is to design institutions that produce desirable outcomes while recognizing that agents have private information and are self-interested. ${ }^{20}$ Rules become institutions only if they are enforced—via self-enforcement or an "external" enforcer. The incentives of the governed and those of potential enforcers become critical issues in designing the institutional mechanism.

\footnotetext{
${ }^{20}$ Hence the mechanism design theory reverses tradition by starting from a set of desired goals and then working to identify what kind of institution (mechanism) is needed to reach these goals. Yet most institutional (and New Institutional) economists seek to analyze existing economic institutions in order to explain the observed economic outcomes.
} 


\subsubsection{Institutions as Self-Enforcing Expectations}

In contrast to the theory just described, the second branch of thought defines an institution as the endogenously derived "play of the game" or strategies created when agents repeatedly interact in a particular situation (for a pioneering analysis, see Schotter, 1981; for contemporary developments, see Aoki, 2001 and 2010; Greif, 2006). Some scholars emphasize the regularity of behavior (or rules of conduct) as the main criterion defining an institution (Schotter, 1981; Sugden, 1989). A given strategy (driving on the right) ends up being the "conventional" way to play a particular simple coordination game. Other authors focus more specifically on the beliefs that motivate these behaviors. For instance, Aoki (2001) defines an institution as a system of self-sustained, shared beliefs regarding the way a game is repeatedly played. These shared beliefs generate behavioral rules that "stabilize" and thereby reduce the complexity of social interactions. However, the contrast between these viewpoints is not that sharp: in any event, individual behaviors become compatible and end up as a "social regularity" because they are based on beliefs (about others' strategies) that are confirmed in equilibrium. Yet the self-enforcing nature of mutual expectations about behavior does raise the issue of the relationship between behavior and motivation; as discussed in Greif and Kingston (2010), it is a complex matter to disentangle extrinsic from intrinsic motivations.

\subsection{Institutional Evolution}

\subsubsection{Changing the Rules of the Game}

When an institution is defined as set of (exogenous) constraints expressed through rules, institutional change is all about changing the rules. But the ability to change might depend on the type of institution under scrutiny. For instance, Williamson (2000, pp. 596-97) describes a 
hierarchy of institutional levels ranging from social embeddedness (informal institutions such as cultures and conventions) to bilateral agreements between firms (see also Ostrom, 2005; Roland, 2004). The higher a rule is in this hierarchy, the slower it is to change. ${ }^{21}$

Most of the literature focuses on the evolution of formal rules such as laws, regulations, and political orders. These formal rules are generally understood as the result of political bargaining between various groups or coalitions. Institutional evolution is then analyzed as the result of political strategies involving alliances, conflict, bargaining, and lobbying (Acemoglu and Johnson, 2005; North, 1990). Institutional change results then from the confrontation between coalitions of agents promoting new rules and others favoring the status quo. Several factors contribute to institutional change: the evolution of relative prices may trigger new ways to allocate resources and new market opportunities; technological evolution may create new opportunities that can become profitable only if property rights are appropriately conducive or redesigned; ${ }^{22}$ and changes in preferences may create new markets and/or feed sociopolitical movements that promote or curtail particular rules. ${ }^{23}$ All these factors modify the endowment and bargaining power of individuals and groups and can therefore reshape coalitions. Also, the balance of power among coalitions may (endogeneously) evolve in reponse to the strategic games they play. Brousseau and Raynaud (2011) propose a framework for analyzing the various strategies available to "institutional sponsors" that promote the adoption of their preferred collective rules by those with which they interact frequently; the result is head-on competition between alternative institutional solutions. The literature on coalitions is discussed more extensively in Sections 4.1 and 4.2.2.

\footnotetext{
${ }^{21}$ Long ago, Schumpeter (1927, p. 262) described this dynamic as follows: “the 'superstructure' of law, custom and so forth is always the last to change, always lags behind changes in the actual life situation."

${ }^{22}$ However, this does not mean that the state should be the only provider of effective property rights or enforcement devices. Private initiatives under some kinds of "private orders" can fill the gap.

${ }^{23}$ North (2005) adds to this list a change in individual beliefs.
} 
Formal rules may be either created endogeneously or imported. In the latter case, the literature on "legal transplants” emphasizes (among other things) the potential misalignment of imported institutions with preexisting ones and the resultant unexpected and possibly undesirable impacts (see Berkowitz et al., 2003). This analysis applies in particular to the impact of exogenous institutional shocks resulting from military conquest and colonization. ${ }^{24}$ However, there are also many instances of independent countries deliberately choosing to implement institutions borrowed from other jurisdictions in order to fill an institutional vacuum, save time, and/or adapt to processes of regional or global integration, political or economic. For instance, many postsocialist countries have transplanted legal rules from other jurisdictions. In such cases, the institutional evolution's endogeneity (since transplants are promoted by some groups) should be recognized: it is highly relevant to analyses of how the political game and other factors influence institutional evolution (as in Grajzl and DimitrovaGrajzl, 2009; Mukand and Rodrik, 2005).

Path dependence plays an important role (North, 1990). Since previous institutions partly shape the relative bargaining power of different players and since institutional changes may result in the redistribution of costs and benefits among agents or groups (Libecap, 1989; Pirrong, 1995), institutional change is strongly influenced by history. As long as the coalitions promoting new rules are unable to defeat or compensate for those who can block or slow down evolution, the status quo may prevail (see, e.g., Acemoglu and Johnson, 2005; Ostrom, 2005). This point is made also by Berkowitz and DeJong (2011) with respect to the contrasting paths of transitions in post-Soviet Russia. In the end, political dynamics play a leading role in shaping the development of economic institutions. Berkowitz et al. (2003) show that the effects of legal transplants depend on the context of implementation. This serves

\footnotetext{
${ }^{24}$ Even though the long-term impact of these shocks is not systematically negative; see Acemoglu et al. (2010) regarding the spread of institutions inherited from the French Revolution by the Napoleonic conquests.
} 
to illustrate the other main factor behind the "path dependency" of institutional evolutionsnamely, institutional complementarities.

There has been much less analysis of informal institutions. Explicit bargaining is less relevant to explaining the evolution of informal rules. Most of this literature suggests that informal institutions are "slow moving" ones (Roland, 2004), in part because they are the result of unintentional and decentralized patterns of behavior and processes of learning. Informal rules evolve slowly because they cannot be formally negotiated among groups; as a result, they advance through incremental processes of local innovation, imitation, and progressive adoption. Selection is assumed to play a strong role here, albeit with the limits on analysis of related processes that were identified in Section 2.2.2.

That being said, Brousseau et al. (2010) and Wallis (2011) attempt to explain the nature of and impetus for evolution from informal institutions (based on interpersonal relationships) to formal institutions (based on the impersonal guarantee of rights to all) in a (mostly) “institutions as rules" framework in which impersonal orders yield superior outcomes, while the evolutionary process can be trapped in inefficient equilibria.

\subsubsection{Switching across Equilibria}

Rather than focusing on the strategies aimed at impacting on the rules of the game, the alternative approach considers how the evolution of behaviors and beliefs drives institutional changes. For those examining behavioral regularities, institutional change is a function of how particular mutually responding behaviors are selected through an evolutionary process (Young, 1996, 1998). As explained in Section 2.1, key elements to understanding institutional change include the possibility of error or experimentation, imperfect memory, and "local" information. When beliefs become the cornerstone of institutional analysis, a central 
task is to explain how a prevailing set of beliefs becomes destabilized and how new shared beliefs emerge. A prevailing equilibrium of beliefs can be destabilized when those beliefs cease to be useful guidelines for understanding and predicting the strategies of others. Aoki (2001, 2010) describes this scenario as a "general cognitive disequilibrium”. In this situation, the cognitive limits of agents become more binding. Agents must now process more information because the previous institutions no longer effectively summarize what players can expect from each other. Therefore, individual agents become more inclined to explore new ways of playing the game.

Destabilizing factors related to previous beliefs may be external ones, such as technological evolution, changes in preferences, new information, and evolution in related games (see Aoki, 2001, Chap. 9). Greif and Laitin (2004) and Greif (2006) also stress the importance of endogenous institutional change, whereby repeated play of the game endogenously creates conditions that increase (or undermine) the sustainability of the prevailing institutions under consideration. ${ }^{25}$ Greif and Laitin (2004) express this idea as changes in "quasi parameters": the set of factors considered to be given or parametric when one studies the (self-) enforceability of a given behavior but considered to be variables when one studies institutional change.

In the face of destabilizing factors, agents attempt to restore stability by converging toward a new set of shared beliefs. As stressed by Aoki (2001), the new beliefs may come from different sources and partly depend on the specific social interactions of interest. New sets of shared beliefs may emerge spontaneously, or the new focal point may be rooted in

25 For instance, Greif (2006, Chap. 10) analyzes the transition in the Middle Ages from a community responsibility system (CRS) to individual responsibility. The CRS allowed for an expansion of intercommunity exchanges. However, this "success" triggered an increase in the costs of running the system (higher information costs, higher frequency and costs of conflicts, etc.), which undermined the system's effectiveness. Thus, the CRS system was not self-reinforcing but rather self-undermining. Wallis (2011), although grounded in the “institutions as rules” approach, reasons similarly. 
previous experiences. Path dependence plays a role here, too, as previous equilibriums may reduce the set of feasible new options. Organizational innovations promoted by some entrepreneurs may change traditional patterns of doing business, compelling others to follow. ${ }^{26}$ Competing political leaders may promote new beliefs by supplying various types of ideologies and related policies. Whether spontaneous or generated by (self-interested) actors, the new sets of beliefs that emerge during an institutional crisis compete until one set becomes the new institution. Various drivers of institutional change and different providers of new beliefs have been scrutinized, but the processes by which convergence is achieved has not been fully explored. For instance, analysis of the competition between alternative new “subjective visions” remains underdeveloped.

In fact, the literature highlights many factors that might explain the diversity of paths to establishing new equilibria. First, the timing of micro decisions matters; this is pointed out, for instance, by Kingston (2007) and Neal (forthcoming). The choice between two alternative social technologies could well depend upon the historical sequence (à la Arthur, 1989) that ensured the success of one of them in some place at some time. Second, the ability of organizations (and of all kinds of leaders) to promote their preferred equilibria should depend upon the nature of the institutional disequilibrium, since their capacity to influence the expectations of others depends strongly on the stability of the organizations or networks through which leaders can act. Third, competition among various leader types must be examined-as proposed by Greif and Tadelis (2010), who analyze how political rulers may attempt to manipulate beliefs. Indeed, values empower leaders by lending them legitimacy and hence constraining the domains of feasible alternatives. In society, all kinds of leaders (parental, religious, etc.) may compete to influence “socialized” agents. This competition may

\footnotetext{
${ }^{26}$ Dixit (2009) gives the example of J.P. Morgan, which voluntary began publishing quarterly accounts of its operations.
} 
explain the persistence of crypto-institutions in the face of a hostile and powerful political leaders.

Sometimes, however, the evolution of equilibria in a society might be driven by incremental paths of changes due to viral effects triggered by imitation. Thus new institutions are created not in the context of crisis but rather by a progressive process of gradual transformation. For instance, Guirkinger and Platteau (2010) analyze the competition among "social technologies" (in their case, farmland regimes) — and demonstrate how viral diffusion among agents can result in the transformation of macro parameters (e.g., the development of anonymous and long-distance trade)—in a framework comparable to the one proposed by Greif and Laitin (2004). Another driver of evolution is the endogenous evolution of preferences; this factor is explored by an emerging literature (see, e.g., Bowles, 1998; Hodgson and Knudsen, 2004).

\subsubsection{Two Views of the Relationship between Institutions and Behaviors}

The two approaches described previously have a different understanding of the relation between individuals’ behaviors and (social) rules. In the “equilibrium view”, institutions and behaviors are of the same nature simply because institutions consist of recurrent behaviors. A particular behavior (out of many) emerges as the conventional way of behaving and, once it's established, agents follow it most of the time because it is their best response. From this perspective, changing institutions is about changing behaviors through a modification of (shared) beliefs. In the "Northian view", rules are constraints on the space of possible choices; therefore, behaviors and rules are not of the same nature. Agents can adopt different patterns of behaviors as long as they remain within the boundaries of the constraints. Given their 
preferences, agents choose their behavior as a function of the costs and benefits of alternatives. $^{27}$

This distinction between behaviors and rules has consequences for the dynamics of institutions. The conditions under which individual choices affect the system of collective rules become central. In the "equilibrium view", the link between (de facto) rules and behavior is simple because a change in behavior is identified with a change in institutions. In the "Northian view", the landscape is richer in that agents may deploy different strategies within a given institutional framework; this means that it is possible for different equilibria to evolve. From this perspective, changed outcomes may result either from different combinations of strategies of from a transformation of the institutional framework. In the latter case, however, changed rules may lead to different and unexpected outcomes; this accounts for the importance of difficulties in targeting goals when manipulating institutions.

\section{The Economics of Institutional Transformation}

In this section we consider literatures that adopt the point of view of those agents who seek to change, or at least influence, the evolution of institutional frameworks. This literature employs one of the perspectives discussed in Section 3: institutions are understood as “designed rules of the game” and can be voluntary changed.

The literature on institutional transformation has developed significantly over the past two decades. ${ }^{28}$ The transition in formerly communist countries triggered this analysis, which

\footnotetext{
${ }^{27}$ Conversely, one can say (echoing Greif and Kingston, 2010) that, in the "institution as rules” approach, rules combined with enforcement mechanisms influence behaviors, which facilitates coordination. In the "institution as equilibrium” approach, rules are the institutional components that coordinate behaviors.

${ }^{28}$ Three issues in particular have dominated the academic literature on the political economy of reforms: (1) the reduction or elimination of trade barriers and tariffs (see Rodrik, 1993, for the case of trade barriers); (2) the transition to a market economy under the so-called Washington Consensus (see Roland, 2002); and (3) the reform of post-WWII Western institutions-especially in the context of globalization of the economy and retirement of the Baby Boomers. The overriding importance of political constraints on these processes has led to
} 
was then extended to the question of development. The literature started with a simple question: How should transition to a given institutional model be organized? The failure of many countries to implement a market economy led then to a broader research question: Why do transitions so often fail? The aim is to identify barriers to reform and possible strategies for overcoming them. From a historic standpoint, two perspectives have been considered: a topdown approach of administrated change in which enlightened reformers seek to implement institutional change; and a bottom-up approach in which social groups try to impose institutional changes on a ruling elite that is able and willing to block reforms (although this elite may be internally fragmented). The two perspectives do not engage the same historical horizon. Whereas the top-down approach is primarily concerned with policy implementation, the bottom-up approach is more concerned about the longue durée-namely, social evolution that requires more than a single generation to transpire. However, the two approaches are complementary in the sense that top-down reform policies may enable or accelerate endogenous processes of institution building.

Following our "descaling" logic, we start in Section 4.1 by discussing the bottom-up approach that characterizes the recent political economy of institutional and economic development. We then focus in Section 4.2 on the literature of institutional reforms.

\subsection{Interplay between the Polity, the Law, and the Economy: The Long-Term, Bottom-up Process of Institutional Transformation}

When considering the relationships between institutions and development and the logic of institutional dynamics, recent contributions have highlighted the relationships between several spheres of the societal dynamics (Acemoglu and Robinson, 2005; Brousseau et al., 2010;

developments in theories on the political economy of reform (for surveys, see Dewatripont and Roland, 1995; Roland, 2000). 
Greif, 2006; North et al., 2009; Persson and Tabelini, 2004). In particular, the interplay between the polity, the law, and the economy has been well explored. It remains a subject of debate, however, just which of these factors is the most essential for the promotion of development. We begin by focusing on the interaction between the polity and the economy before turning to that between law and economic development.

In addressing the interaction between the polity and the economy, North et al. (2009) together with Greif (2005, 2006, 2008) develop an analysis of the long-run joint evolution of “political safeguards” (e.g., separation of powers, a constitutional pact) and the economy. These authors place central importance on the transformation of the state from an organization of oppression and extortion controlled by the elite to an impersonal and independent organization, thus allowing the rise of what they call the "open access" society sustaining impersonal exchanges which boost division of labor. In order to do so, the state machinery provides two sets of public goods. First, it guarantees the constitutional pact by credibly bounding the capacity of the rulers to hold up other members of the society. ${ }^{29}$ Second, the state operationalizes the constitution by providing a set of public goods (from security to social protection) corresponding to citizens' rights-thanks to the development of an efficient and neutral Weberian bureaucracy. Jellema and Rolland (2011) provide evidence that confirms this statement.

This transformational analysis does, however, raise fundamental questions that are shared by many authors (Acemoglu and Robinson, 2006; Barro, 1999; Djankov et al., 2003; Giavazzi and Tabellini, 2005; Olson, 1993). Namely: How do these efficient (and benevolent) state and public bureaucracies emerge? Under what conditions would a powerful and wellestablished despot or oligarchy renounce its privileges and wealth? Answers to these

\footnotetext{
${ }^{29}$ Indeed, as nicely stated by Weingast (1995, p. 1), “a government strong enough to protect property rights and enforce contracts is also strong enough to confiscate the wealth of its citizens.”
} 
questions are based on a bottom-up approach in which institutional changes result from coalition building and from the evolution of the distribution of bargaining power toward citizens within the society. Fundamentally, institutional change is perceived as a process of bargaining between a ruling elite (which is able to capture rents but must consider the costs of maintaining a given social order) and the governed who seek enfranchisement-in particular, to benefit from economic opportunities. ${ }^{30}$ This literature is still developing, and there is neither agreement about nor convincing tests on the nature of the process (revolutionary or gradual), the institutional characteristics (or their combination) actually favoring growth, or the barriers that now prevent growth-enhancing institutional reforms. Beyond evolutions of coalitions, the discovery of more efficient social compromises could also be a factor explaining institutional evolution. For instance, democracy and many institutions linked to open-access societies have come to be recognized as simply more efficient than a dictatorship because they permit stabilization of the economy's functioning. Rulers have incentives both to enforce the rule of law and to take into account the claims of citizens, most of whom are thus induced to play the civic game instead of breaking the law or rebelling. This result in reduced enforcement costs and less energy dedicated to the zero-sum game of conflict and predation (see North et al., 2009). Finally, progress in knowledge could play a role in modifying the expectations and preferences of social actors. This path of analysis, however, remains at the level of providing insights.

Beside the emergence of a state providing the infrastructure of a market economy, the rule of law is a second pillar of formal institutions favoring economic growth and societal development. In the line of Posner, several contributions insist on the central role of legal

\footnotetext{
${ }^{30}$ The originality of the thesis developed by North et al (2009) is however to consider that the game is played within a multilayered elite and not between the elite and the lower strata of the society. This is why they focus on "horizontal" rather than "vertical" negotiations and arrangements.
} 
institutions in shaping social interactions, negotiations, disputes and their settlements, and the impact of all these factors on economic performance. This does not mean that the vision popularized by Posner-according to which decentralized legal bargaining, which characterizes the logic of Common Law, is intrinsically superior to the supposed centralized logic of Civil Law—should be embraced. One could hardly assume that the two types of legal regimes have such contrasting abilities to consider and learn from specific cases. The usual wisdom is that case law in the Common Law framework allows for continual adaptation to innovation in social practices and the evolution of preferences. However, several scholars remark that designers of the code in Civil Law countries also take into account both the evolution of the social norms (whence the subdiscipline of "legal doctrine" that is grounded in philosophy) and the possible maladaptation of the legal framework as revealed by courts or by citizens who try to influence politicians in the Parliament (see, e.g., Deffains and Kirat, 2001). More generally, Hadfield (2011) develops an in-depth analysis of the institutional parameters favoring the adaptability of legal rules; she argues that the judiciary's organization matters more than the legal origins. In any case, if the law is able to evolve with practices and is flexible enough to fit the diversity of socioeconomic needs, then legal institutions enable a mutual recognition of rights among socioeconomic actors and form the basis for further renegotiation and possible redesign toward the end of reaching a higher level of efficiency. In addition, the "rule of law" per se reduces violence and social disorder while facilitating credible commitments among members of society. These outcomes favor long-term investment, risk sharing, the settlement of organizations, and innovation, which combination favors the division of labor, knowledge creation, and accumulation (Brousseau et al., 2010). 


\subsection{The Political Economy of Implementing Reforms: The Policy Horizon of Top-Down Institutional Change ${ }^{31}$}

In the literature on the political economy of reform (PER), processes of institutional change are analyzed in terms of an enlightened elite seeking to implement "enhancing" reforms in a conservative society characterized in part by the will to preserve rents. Thus the PER literature reverses the logic of those works reviewed in the previous section. The aim of PER literature is to identify and better understand the factors behind successful reforms. The field has mostly developed since the 1990s in the context of transitions of former planned economies to market economies; however, it has been enriched by the analysis of many processes of policy reforms in the most advanced countries.

Reformers face two types of political constraints. One type consists of feasibility constraints, called ex ante political constraints, which can block decision making and prevent reforms from being accepted. The second type, called ex post political constraints, is related to backlash and policy reversal after reforms have been implemented and the outcomes observed. Section 4.2.1 is devoted to presenting the various ex ante political constraints. Section 4.2.2 describes how these constraints can be relaxed, and Section 4.2.3 focuses on the sustainability of reforms.

\subsubsection{Constraints and the Feasibility of Reforms}

The ex ante and ex post political constraints would, in effect, be the same except for the presence of uncertainty and reversal costs. In the face of uncertainty, a majority may oppose the enactment of particular reforms even though they could end up benefiting the majority and would not be reversed if implemented (Alesina and Drazen, 1992; Fernandez and Rodrik,

\footnotetext{
31 This section draws substantially from Roland (2000); see also the development in Kingston and Caballero (2009). Here we focus only on some seminal contributions and do not review this vast literature in detail.
} 
1991). The reason is that winners from reform cannot credibly commit to compensating ex post the losers from reform, a fact that leads the uncertain majority to refuse proposed changes (Acemoglu, 2003). A government is therefore needed as a neutral guarantor of future redistribution among groups. However, establishing the government's credibility is also a challenge. Another factor increasing the cost and difficulty of change is the fragmentation of society into a large number of varied and possibly conflicting groups, which renders their interactions more complex (for empirical evidence of this claim, see Dollar and Svensson, 2000; Veiga, 2000).

A complementary and more straightforward explanation of the difficulties of reform stems from the possibility that potential losers have enough political influence to block the implementation of reform. Although such groups cannot directly prevent reforms, they have leverage because the political elite rely critically on them for support (for an overview of models of special-interest groups, see Grossman and Helpman, 2001). Cukierman et al. (1992) and Svensson (1998) show that specific groups block reforms in order to avoid development of the state's capacity-not because the current policy is against their interest but because they fear, in the long run, policies that could be implemented by newcomers in power. This reasoning underlies the work of Acemoglu and Robinson (2006), who analyze inefficiencies in the bureaucratic organization of the state in many developing countries as resulting from the elite's strategy to retain its rents. ${ }^{32}$

Political regimes and electoral rules will affect the outcome of such conflicts, and so the feasibility of a given reform differs from one country to another in light of different balances of the national versus local interest in public decision making. Persson and Tabellini

\footnotetext{
${ }^{32}$ Analyses that focus on transition or developing countries can be related to a number of other strands of the literature in political economy and especially to the political economy of democratic systems in which the elite choose inefficient institutions to control political power-either because doing so is in the elite's best interest (Acemoglu and Robinson, 2005) or because of lobbying (Grossman and Helpman, 1996).
} 
(2004) analyze how different kinds of electoral rules and forms of government affect the accountability of government and the size of political rents and corruption as well as the representativeness of government and a variety of fiscal policy choices. In some cases it may be that political reforms (e.g., change of electoral rule, fiscal regime, or level of government) are required to allow bypassing or overcoming groups of localized interest that threaten or obstruct the viability of economic and social reforms.

North et al. (2009) propose a different perspective that highlights the role of violence in social equilibria. Established structures are low-violence coalitional equilibria. Because reform might disturb the equilibrium, the trick is to find a stable transition path to open-access institutions without incurring social disorder, since the resulting violence could engender coalitions seeking to block reforms.

\subsubsection{Relaxing Political Constraints to Enact Reforms}

There are three possible strategies for easing political constraints so that reforms can be enacted: (i) building reform packages that give losers compensating transfers; (ii) making reforms only partial and gradual to reduce opposition; and (iii) waiting for the status quo to deteriorate so that reform appears more attractive. We will discuss each strategy in turn.

Beyond the distortions due to taxes, the risk of overcompensating some stakeholders (Dewatripont and Roland, 1992a; Lewis et al., 1989), and the potential default on commitments to compensate, the essential concern with compensating losers is that, given typical political games, compensation will more likely be geared toward the relatively welloff than toward the most vulnerable groups. Moreover, compensation may empower groups 
that later emerge as vested interests against further reform, ${ }^{33}$ a dynamic that also characterizes intergenerational transfers via budget deficits.

Although gradualist strategies have some clear disadvantages, ${ }^{34}$ the literature trumpets the many advantages of partial reforms-for example, reduced compensation payments to losers and greater political acceptability. In addition, gradualism favors efficient implementation because it facilitates the management of institutional complementarities (joint reforms) and favors learning and experimentation (Dewatripont and Roland, 1992a, 1992b, 1995; McMillan and Naughton, 1992; Murrel 1992; Wei, 1997). The argument is simply that gradual reforms allow for the identification of potential errors and of ways to deal with them. After Aoki (2001), one could add that they should also facilitate convergence of beliefs.

Political economy suggests that the key issue in the management of reforms is the joint management of (a) a political climate that is favorable to reforms and (b) the consequences of reform itself. In particular, suboptimal sequencing of reforms may result in massive transfers of wealth and/or generate instability, which could favor the consolidation of a coalition of opponents to reform. In that perspective, two strategies are prominent in the literature. First is the "divide and rule" tactic (Dewatripont and Roland, 1992a; Wei, 1997), which consists of negotiating changes with successive interest groups. To each group, reformers propose better compensation from negotiating than would result if the reform were imposed. Since the status quo is no longer safe, most stakeholders end up accepting the reform, including those for whom its immediate impact will be negative. The reform is then accepted despite incomplete compensation of each group. Second, the “dual track” strategy (Lau et al., 1997, 2000)

\footnotetext{
33 These two last points are well illustrated by Shleifer and Treisman's (2000) analysis of the Russian transition. 34 Disadvantages pointed out by partisans of "shock therapy" are the reversibility of partial reforms (and hence the possible reinforcement of opponents whose mobilization en masse could be difficult to overcome), the risk of incomplete reforms, and delays in realizing the benefits. See, for instance, Balcerowicz (1995) and Boycko et al. (1995)
} 
consists of avoiding the creation of losers by applying a reform only to those who were not previously beneficiaries of the institutional arrangement. By construction, then, the system preserves the rents of various economic agents under the old system while creating new rents with the new rules of the game. Because of its Pareto-improving property, the dual-track approach minimizes political opposition to reform ex ante and maximizes political opposition to the reversal of reform ex post. Moreover, the continuance of the old arrangement can reduce the disorganization effects of reforms and thereby contribute to political and economic stability. However, sufficient state credibility is required to guarantee a reform that creates only winners.

In some cases, political or institutional impediments to reform may be so fundamental that reform will be impossible until a true crisis emerges, one that causes enough deterioration in the status quo to make previous adversaries in favor of (or less able to oppose) reforms. A crisis typically leads to a sense of urgency that creates a "window of opportunity". However, as is generally the case for "big bang" strategies, decisions made in mid-crisis often lead to inefficient outcomes that are difficult to reverse ex post, and interest groups can capture the process of reform in their favor.

\subsubsection{Sustainability: Preventing Reversal of Reforms}

“Good government”-specifically, expanding political constraints on policy decisions by strengthening the legislative branch, making the civil service more transparent, improving the independence of judiciaries, and enhancing both the autonomy and responsiveness of subnational governments-has been identified by the literature as a relevant strategy for preventing "reform fatigue”.

In particular, increasing the transparency and accountability of the political process is essential to reducing the risk that decision making will be captured by the well-connected elite 
and winners from partial reform. Suggested remedies include increasing the voice of the winners from continuation of the reform process - through empowerment of consumers, workers, and the new entrepreneurial groups without political affiliations-as well as increasing transparency and enforcing the accountability of political leaders. However, this general acknowledgement of the need to pair economic reforms with reforms of political institutions (see Kuczynski, 2003) reverses conventional wisdom of the early 1990s, when strategists typically emphasized the need to insulate reformers from public pressures (Williamson, 1994).

In a more generic framework that applies mainly to regulation, several authors analyze_-along the lines of Spiller and colleagues (Guash and Spiller, 1999; Levy and Spiller, 1996; Spiller, 1996; Spiller and Tommasi, 2003) - the complex web of forums and collective decision-making processes in which so-called veto players can block, significantly amend, or reverse reforms at their implementation stage. This "political strategy” literature (for reviews, see De Figueiredo, 2009; Glachant and Perez, 2008) combines political analyses of administrative and legal procedures (Epstein and Knight, 1998; McCubbins et al., 1987, 1989; Tsebelis, 2002) with transaction-cost approaches to firms' strategies (De Figueiredo and De Figueiredo, 2002; Zelner and Henisz 2009), and it highlights the many ways in which interest groups can influence the process of policy reforms with complex effects on desirable institutional design. For instance, institutional frameworks that are more stable (have more checks and balances) offer fewer opportunities for interest groups to promote their own favored reforms. At the same time, such frameworks stimulate lobbies' efforts to influence institutional design, since the payback is potentially higher and longer-lasting. These observations may lead to the development of an endogenous analysis of reform processes whereby the feasibility of reform depends not only on the balance of political forces but also on institutional design, given that the latter constrains the set of implementable strategies. 
Note also that the various players may differ in their ability to implement a given strategy (because of their differing initial endowments in terms of competence, human capital, wealth, etc.) given the institutional setting.

\section{CONCLUSION}

The complex dialectic between elements of change and stability almost certainly accounts for why the economics of institutions is still unable to propose clear political recipes for building institutional settings and "driving" institutional reforms. Even if institutional policy is increasingly recognized as a more powerful policy instrument than direct governmental intervention via tax and/or subsidies, economists remain limited to proposing "insights" on how to implement reforms. Nevertheless, significant advances have been made over the last fifteen years in our understanding of the nature of institutions and in the analysis of their dynamics. In this paper-beyond detailing the specifics, stating the field's main results, and listing the shortcomings still to be overcome by the various approaches-we have focused on issues whose transversality should be emphasized. These include the multilayered nature of institutions, the interdependencies among institutional components characterized by contrasting paces and logics of evolutions; the strong role of interpretation (of rules and of others' behaviors and expectations) in the stability of institutional systems; the influence of time and sequencing; and the disconnection between efficiency and sustainability of institutional systems. Finally, it is difficult to identify simple yet adequate criteria of efficiency for normatively assessing alternative institutional designs or evolution processes or simply to set and assess agents' strategies.

A deepening of our understanding of processes of institutional establishment and evolution will require so many further developments, including those in contributions from other social and human sciences, that it would be meaningless to attempt listing them in a 
survey such as this. However, in this section we briefly discuss two sets of issues that are transversal to most approaches to institutions and should be better addressed: the consequences of complexity and of bounded rationality. Indeed, both factors play an essential role in the puzzle highlighted in the introduction: that both institutional stability and evolution are endogenous and probably linked to the same causal factors.

\subsection{Complexity of Institutional Games}

An institutional framework comprises many heterogeneous and interacting components, which makes it complex to understand and difficult to change. The heterogeneity and entangling of the components of institutional systems explain their stability because these elements and compromises do not evolve in compatible ways at the same moment. Many mechanisms attract an evolving system back to its initial equilibrium. This essential characteristic of an institution is both its strength and a constraint. Stability is essential because human action is grounded on the rights and collective capabilities provided by a given institutional setting. Stability enables predictability and hence security, which favors investment and economic ventures. On the other hand, institutional systems are difficult to transform because they establish relative positions in political and economic competition and because they result from compromises, explicit or implicit, among a wide set of stakeholders.

The "new" political economy literature typically focuses on these types of games with the aim to understand why sociopolitical systems might become trapped in (inefficient) equilibria, to analyze the conditions under which evolution toward increased institutional efficiency may occur, or to determine an optimal balance between stability and efficiencyenhancing evolution. In addition, many stakeholders-including those who might benefit from changes-have a strong preference for stability because interdependencies and the strategic behavior of other players make it difficult to foresee the outcome of a change and 
also because the process of change is known to be difficult to monitor.

Yet there simultaneously exist drivers for changes, notably the quest to secure individual wealth and capture rents (including those now benefiting the incumbents). Hence institutions are the arena of multiple competitive processes each promoting stability or change. A better understanding of endogenous sources of change lies in analysis of the sequencing of (institutional) games, the interplay among institutional components, the strategies by which agents explore new coordination solutions, and the way these solutions spread in social structures.

\subsection{Cognitive Boundaries}

In addition to the constraints due to the diversity of a society's stakeholders and the complexity of compromises among them, the bounded cognitive capacity of social agents comes into play at two levels. First, there may exist no collective understanding on the actual coordination needs and best institutional solutions (see Brousseau et al., forthcoming, with respect to environmental issues). In such cases, collective goals are unknown because an individual or community can form preferences only by becoming conscious of the actual stakes and of how those stakes affect its own individual situation, the situations of others, and future members of society. The lack of required knowledge necessary to reach sound collective decision is not only linked to a "revelation" problem (as traditionally occurs in the provision of a public good), but also to a lack of understanding by agents which prevent them to establish complete set of preferences. Furthermore, solutions might be unknown also because the most efficient way to deal with a problem is unclear and/or because the diffusion of the relevant knowledge to the decision makers in imperfect. How institutions favor (or not) collective learning, innovation, and more generally the genesis and recombination of the knowledged dispersed throughout society—both to gain more informed collective preferences 
and to identify solutions to collective problems—is the crux of understanding institutions.

Second, individual myopia favors "short termism”, preference for stability, routinized behaviors, and so forth. Recognizing this fact enables a better understanding of the role of institutions as both a source of stability and a tool of change. This recognition clarifies in particular the role of perception and legitimacy in any dynamic effect, and it leads us to point out the "bricolage” aspect of any process of institutional evolution (as identified by Campbell, 2004). Most processes of institutional evolution are characterized by incremental adaptation of past institutions to new problems faced by individuals. Therefore, analysis of the interplay between invividual mental models and institutional scaffolds is an essential route to be explored. 


\section{REFERENCES}

Acemoglu, D., 2003. Why not a political Coase theorem? Social conflict, commitment and politics. Journal of Comparative Economics 31, 620-652.

Acemoglu, D., Cantoni, D., Johnson, S., Robinson J.A., 2010. The consequences of radical reform: The French revolution. NBER Working Paper No. 14831.

Acemoglu, D., Johnson, S., 2005. Unbundling institutions. Journal of Political Economy 113, 943-995.

Acemoglu, D., Robinson, J.A. 2005. Economic origins of dictatorship and democracy. Cambridge: Cambridge University Press

Acemoglu, D., Robinson, J.A., 2006. De facto political power and institutional persistence. American Economic Review 96, 325-330.

Alchian, A.A., 1950. Uncertainty, evolution and economic theory. Journal of Political Economy 58, 211-221.

Alesina A., Drazen, A., 1992. Why are stabilizations delayed? American Economic Review $81,1170-88$.

Aoki, M., 2001. Towards a comparative institutional analysis. Cambridge Mass.: MIT Press.

Aoki, M., 2010. Corporations in evolving diversity, cognition, governance, and institutions. Oxford: Oxford University Press.

Aoki, M., 2011. Institutions as mediating the cognitive and physical aspect of social dynamics. Journal of Economic Behavior and Organization, this issue.

Arruñada, B., Garoupa N., 2005. The choice of titling system in land. Journal of Law and Economics 48, 709-27.

Arthur, W.B., 1989. Competing technologies, increasing returns, and lock-in by historical events. Economic Journal 99, 116-131.

Axelrod R., 1986. An evolutionary approach to norms. American Political Science Review 80, 1095-1111.

Balcerowicz L., 1995. Socialism, capitalism, transformation. Budapest: Central European University Press.

Barro R., 1999. The Determinants of democracy. Journal of Political Economy 107, 158-183.

Barzel, Y., 2002. A Theory of the state: economic rights, legal rights and the scope of the state. Cambridge: Cambridge University Press.

Bénabou, R., Tirole, J., 2006. Incentives and prosocial behavior. American Economic Review 
96, 1652-1678.

Bénabou, R., Tirole, J., 2007. Identity, dignity and taboos: beliefs as assets. CEPR Discussion Paper 6123, February.

Berkowitz, D., DeJong, D., 2011. Growth in post-soviet Russia: a tale of two transitions. Journal of Economic Behavior and Organization, this issue.

Berkowitz, D., Pistor, K., Richard, J.F., 2003. The transplant effect. American Journal of Comparative Law 51, 163-204.

Bernstein, L., 2001. Private commercial law in the cotton industry: creating cooperation through rules, norms and institutions. Michigan Law Review 99, 1724-1790.

Binmore, K., 2010. Game theory and institutions. Journal of Comparative Economics 38, 245252.

Bowles, S., 1998. Endogenous preferences: the cultural consequences of markets and other economic institutions. Journal of Economic Literature 36, 75-111.

Bowles, S., 2004. Microeconomics: behavior, institutions and evolution. Princeton, NJ: Princeton University Press.

Boycko M., Shleifer A., Vishny R.W., 1995. Privatizing Russia. Cambridge, Mass.: MIT Press.

Brousseau E., 2000. Processus évolutionnaires et institutions : quelles alternatives à la rationalité parfaite? Revue Economique 51, 1185-1213.

Brousseau E., Dedeurwaerdere, T., Siebenhüner B., (forthcoming). Knowledge matters: institutional frameworks to govern the provision of global public goods. In Brousseau, E., Dedeurwaerdere, T., Siebenhüner, B. (Eds). Reflexive governance and global public goods. Cambridge, Mass.: MIT Press.

Brousseau, E., Raynaud, E., 2011. Climbing the hierarchical ladders of rules: a life-cycle theory of institutional evolution. Journal of Economic Behavior and Organization, this issue.

Brousseau E., Schemeil, Y., Sgard, J., 2010. Constitution, states and development. Journal of Comparative Economics 38, 253-266.

Camerer, C.F., 2003. Behavioral game theory. New York, and Princeton, NJ: Russell Sage Foundation/Princeton University Press.

Campbell, J.L. 2004. Institutional change and globalization. Princeton, NJ: Princeton University Press.

Chiappori, P.A., 1984. Sélection naturelle et rationalité absolue des entreprises. Revue 
Economique 35, 87-108.

Cukierman A., Edwards, S., Tabellini, G., 1992. Seignorage and political instability. American Economic Review 82, 537-55.

Dari-Mattiacci, G., Deffains, B., Lovat, B., 2011. The dynamics of the legal system. Journal of Economic Behavior and Organization, this issue.

David, P. A., 1985. Clio and the economics of QWERTY. American Economic Review 75, 332-337.

Deffains B., Kirat T., (Eds) 2001. Law and Economics in civil law countries. Amsterdam/Greenwich, Conn : Elsevier, JAI Press.

De Figureiredo J.M., 2009. Integraged political strategy. Advances in Strategic Management: Economics Institutions of Strategy 26, 459-486.

De Figueiredo, J.M., De Figueiredo, R.J.P., 2002. The allocation of resources by interest groups: lobbying, litigation and administrative regulation. NBER Working Paper. Available at SSRN: http://ssrn.com/abstract=315331.

Demsetz, H., 1969. Information and efficiency: another viewpoint. Journal of Law and Economics 12, 1-22.

Denzau, A. T., North, D.C., 1994. Shared mental models: ideologies and institutions. Kyklos 71, 3-31.

Dewatripont M., Roland, G., 1992a. Economic reform and dynamic political constraints. Review of Economic Studies 59, 703-30.

Dewatripont M., Roland, G., 1992b. The virtues of gradualism and legitimacy in the transition to a market economy. Economic Journal 102, 291-300.

Dewatripont M., Roland G., 1995. The Design of reform packages under uncertainty. American economic review 85, 1207-223.

Dixit, A., 2004. Lawlessness and economic governance. Princeton, NJ: Princeton University Press.

Dixit, A., 2009. Governance institutions and economic activities. American Economic Review 99, 5-24.

Djankov S., Glaeser, E., La Porta, R., Lopez-de-Silanes, F., Shleifer, A., 2003. The new comparative economics. Journal of Comparative Economics 31, 595-619.

Dollar D., Svensson J., 2000. What explains the success or failure of structural adjustment programs? Economic journal 110, 894-917.

Eggertson, T., 2005. Imperfect institutions: possibilities and limits of reform. Ann Arbor: 
University of Michigan Press.

Eldredge, N., Gould, S.J., 1972. Punctuated equilibria: an alternative to phyletic gradualism. In Schopf, T.J.M. (Ed.), Models in paleobiology. San Francisco: Freeman Cooper, 82115.

Epstein, L., Knight, J., 1998. The choices justices make. Washington, D.C.: CQ Press.

Fehr, E. Fischbacher, U., 2005. The economics of strong reciprocity. In Gintis, H., Bowles, S., Boyd, R., Fehr, E. (Eds.). Moral sentiments and material interests; the foundations of cooperation in economic life. Cambridge, Mass.: MIT Press., 151-214.

Fernandez, R. Rodrik, D., 1991. Resistance to reform: status quo bias in the presence of individual-specific uncertainty. American Economic Review 81, 1146-55.

Geroski P. A., 2000. Models of technology diffusion. Research Policy 29, 603-625.

Giavazzi F., Tabellini, G., 2005. Economic and political liberalizations. Journal of Monetary Economics 52, 1297-1330.

Gintis, H, Bowles, S., Boyd, R, Fehr, E., (Eds) 2005. Moral sentiments and material interests; the foundations of cooperation in economic life. Cambridge, Mass.: MIT Press.

Glachant, J-M., Perez, Y., 2008. Regulation and deregulation in network industries. In Brousseau, E., Glachant, JM (Eds.). New Institutional Economics: a guidebook. Cambridge: Cambride University Press. 328-362

Grajzl, P., Dimitrova-Grajzl, V., 2009. The choice in the lawmaking process: legal transplants vs. indigenous law. Review of Law and Economics 5, 615-660.

Greif, A., 2005. Commitment, coercion and markets: the nature and dynamics of institutions supporting exchange. In Ménard, C., Shirley, M. (Eds.). Handbook of New Institutional Economics, Boston, Mass.: Kluwer Academic Press, 727-786.

Greif, A., 2006. Institutions and the path to the modern economy: lessons from Medieval trade. Cambridge: Cambridge University Press.

Greif, A., 2008. Toward political economy of implementation: the impact of administrative power on institutional and economic developments. In Helpman, E. (Ed.), Institutions and growth, Cambridge, Mass.: Harvard University Press, 17-63.

Greif A., Kingston C., 2010. Institutions: rules or equilibria? Working paper.

Greif, A., Laitin D., 2004. A Theory of endogenous institutional change. American Political Science Review 98, 633-652.

Greif, A., Tadelis, S., 2010. A theory of moral persistence: crypto-morality and political legitimacy. Journal of Comparative Economics, 38, 229-244. 
Grossman G., Helpman E., 1996. Electoral competition and special interest politics. Review of Economic Studies 63, 265-286.

Grossman G., Helpman, E., 2001. Special interest group politics. Cambridge, Mass.: MIT Press.

Guash J.L., Spiller, P.T., 1999. Managing the regulatory process: design, concepts, issues, and the Latin America and Caribbean story. The International Bank for Reconstruction and Development, the World Bank Washington D.C.

Guerriero, C., 2010. Democracy, judicial attitudes and heterogeneity: the civil versus common law tradition. Working Paper ACLE, University of Amsterdam.

Guirkinger, C., Platteau, J-P., 2010. Transformation of the family under rising land pressure: a theoretical essay. Working Paper CRED, Université de Namur.

Hadfield, G.K., 2008. The levers of legal design: institutional determinants of the quality of law. Journal of Comparative Economics 36, 43-73.

Hadfield, G., 2011. The Dynamic quality of law: the role of judicial incentives and legal human capital in the adaptation of law. Journal of Economic Behavior and Organization, this issue.

Hayek, F. A., 1988. The Fatal conceit, the errors of socialism. Bartley, W. W., III (Ed.).

Hayo, B., Voigt, S., 2010. Determinants of Constitutional Change: Why Do Countries Change Their Form of Government?. Journal of Comparative Economics 38, 283-305.

Hodgson, G.M., Waren, J.S., Tool, M.R. (Eds), 1994. The Elgar Companion to Institutional and Evolutionary Economics. Edward Elgar, Aldershot.

Hodgson, G.M., 1998. The approach of institutional economics. Journal of Economic Literature 36, 166-192.

Hodgson, G.M., 2006. What are institutions? Journal of Economic Issues XL(1), 1-25.

Hodgson, G.M., Knudsen, T., 2004. The complex evolution of a simple traffic convention: the functions and implications of habit. Journal of Economic Behavior and Organization $54,19-47$.

Hurwicz, L., 1994. Economic design, adjustment processes, mechanisms, and institutions. Economic Design 1, 1-14.

Hurwicz, L., 2008. But who will guard the guardians? American Economic Review 98, 577585.

Jellema, J., Roland, G., 2011. Institutional clusters and economic performance. Journal of Economic Behavior and Organization, this issue. 
Kingston, C., 2007. Marine insurance in Britain and America, 1720-1844: a comparative institutional analysis. Journal of Economic History 67, 379-409.

Kingston, C., Caballero G., 2009. Comparing recent theories of institutional change. Journal of Institutional Economics 5, 151-180.

Kuczynski, P-P., 2003. Reforming the state. In Kuczynski, P.P., Williamson, J. (Eds.), After the Washington consensus: restarting growth and reform in Latin America. Washington, DC: Institute for International Economics.

La Porta, R., Lopez-de-Silanes, F., Shleifer, A., 2008. The Economic consequences of legal origin. Journal of Economic Literature 46, 285-332.

Lau L J., Qian, Y., Roland, G., 1997. Pareto-improving economic reforms through dual-track liberalization. Economics Letters 55, 285-92.

Lau L J., Qian, Y., Roland, G., 2000. Reform without losers: an interpretation of China's dualtrack approach to transition. Journal of Political Economy 108, 120-143.

Levy B.; Spiller P. T., (Eds) 1996. Regulations, institutions and commitment. Comparative studies of telecommunications. Cambridge: Cambridge University Press.

Lewis T.R., Feenstra R., Ware R., 1989. Eliminating price supports: a political economy perspective. Journal of Public Economics 40, 159-85.

Libecap, G.D., 1989. Contracting for property rights. Cambridge: Cambridge University Press.

Liebowitz, S. J., Margolis, S.E., 1994. Network externality: an uncommon tragedy. Journal of Economic Perspectives 8, 133-150.

Liebowitz, S. J., Margolis, S.E., 1995. Path dependence, lock-in and history. Journal of Law, Economics \& Organization 11, 205-226.

MacAdams, R. H., Rasmusen, E.B., 2007, Norms and the Law, in A.M. Polinsky and S. Shavell eds, Handbook of Law and Economics vol. 2, Amsterdam : North-Holland.1573-1618

Mantzavinos, C., North, D.C., Shariq, S., 2004. Learning, institutions and economic performance. Perspectives on Politics 2, 75-84.

McCubbins, M.D., Noll, R.G., Weingast, B.R., 1987. Administrative procedures as instruments of political control. Journal of Law, Economics \& Organisation 3, 243277.

McCubbins M.D., Noll, R.G., Weingast B.R., 1989. Structures and process, politics and policy: administrative procedures and the political control of agencies. Virginia Law Review 75, 431- 482. 
McMillan J., Naughton B., 1992. How to reform a planned economy: lessons from China. Oxford Review of Economic Policy 8, 130-43.

Mukand, S.W., Rodrik, D., 2005. In search of the Holy Grail: policy convergence, experimentation, and economic performance. American Economic Review 95, 374383.

Murrell P., 1992. Evolution in economics and in the economic reform of the centrally planned economies. In Clague, C., Rausser, G. (Eds.). The Emergence of Market Economies in Eastern Europe. Blackwell, Cambridge Mass., 35-53.

Myerson, R., 2009. Fundamental theory of institutions: a lecture in honor of Leo Hurwicz. Review of Economic Design 13, 59-75.

Neal, Larry (forthcoming). The microstructure of the first emerging markets in Europe in the 18th Century. In Brousseau E and Glachant JM (Eds.). Manufacturing markets: legal, political and economic dynamics, Cambridge University Press, Cambridge.

North, D.C., 1990. Institutions, institutional change and economic performance. Cambridge University Press, Cambridge.

North, D.C., 2005. Understanding the process of economic change. Princeton University Press, Princeton.

North, D. C., Wallis, J.J., Weingast, B.R., 2009. Violence and social orders: a conceptual framework for interpreting recorded human history. Cambridge: Cambridge University Press.

Olson, M., 1993. Dictatorship, democracy, and development. American Political Science Review 87, 567-276.

Ostrom, E., 2005. Understanding institutional diversity. Princeton, NJ: Princeton University Press.

Persson T., Tabellini G., 2004. Constitutions and economic policy. Journal of Economic Perspectives 18, 75-98.

Pirrong, S.C., 1995. The Efficient scope of private transaction-cost-reducing institutions: the successes and failures of commodity exchange. Journal of Legal Studies, 24, 229-255.

Platteau, J-P., Sekeris, P.G., 2010. On the feasibility of power and status ranking in traditional setup. Journal of Comparative Economics 38, 267-282.

Pólya, G., 1957. How to solve it. Doubleday, Garden City NY.

Posner, R., 1973. Economic analysis of law. Little, Brown.

Priest, G.L., 1977. The Common law process and the selection of efficient rules. Journal of 
Legal Studies 6, 65-82.

Rodrik D., 1993. Trade and industrial policy reform in developing countries: a review of recent theory and evidence. NBER Working Paper No. W4417. http://ssrn.com/abstract $=252200$

Rodrik, D., 2008. Second-best institutions. American Economic Review 98, 100-104.

Rodrik, D., Subramanian A., Trebbi F., 2004. Institution rules: the primacy of institutions over geography and integration in economic development. Journal of Economic Growth 9, 131-165.

Roland G., 2000. Transition and economics: politics, firms, markets. Cambridge, Mass.: MIT Press.

Roland G., 2002. The Political economy of transition. The Journal of Economic Perspectives $16,29-50$.

Roland, G., 2004. Understanding institutional change: fast-moving and slow-moving institutions. Studies in Comparative International Development 38, 109-131.

Schotter, A., 1981. The Economic theory of social institutions. Cambridge: Cambridge University Press.

Schumpeter, J.A., 1927. Die sozialen klassen im ethnisch homogen milieu. Archiv für Sozialwissenschaft und Sozialpolitik 57, 1-67. Translated into English as "Social classes in an ethnically homogenous environment” in Schumpeter, J. A. 1951. Social Imperialism and Classes, edited by P. Sweezy. New York: Augustus M. Kelley.

Shleifer A., Treisman D., 2000. Without a map: political tactics and economic reform in Russia. Cambridge, Mass.: MIT Press.

Silverberg G., 1994. Formal models of evolution. In Hodgson, G.M., Waren, J.S., Tool, M.R. (Eds). The Elgar Companion to Institutional and Evolutionary Economics. Aldershot: Edward Elgar. 213-17.

Spiller P.T., 1996. Institutions and commitments. Industrial and Corporate Change 5, 421452.

Spiller, P., Tommasi, M., 2003. The institutional foundations of public policy: A transactions approach with application to Argentina. Journal of Law, Economics \& Organization 19, 281-306.

Sugden, R., 1989. Spontaneous order. Journal of Economic Perspectives 3, 85-97.

Sugden, R., 2011. Salience, inductive reasoning and the emergence of conventions. Journal of Economic Behavior and Organization, this issue. 
Svensson J., 1998. Investment, property rights, and political instability: theory and evidence. European Economic Review 42, 1317-41.

Tsebelis G., 2002. Veto players. How political institutions work. Princeton, NJ: Princeton University Press.

Ullmann-Margalit, E., 1978. Invisible hand explanations. Synthese 39, 263-91

Van Baalen, M., Rand, D.A., 1998. The unit of selection in viscous populations and the evolution of altruism. Journal of Theoretical Biology 193, 631-648.

Veiga, F.J., 2000. Delays of inflation stabilization. Economics and Politics 12, 275-295.

Wallis, J.J., 2011. Institutions, organizations, impersonality and interest: the dynamics of institutions. Journal of Economic Behavior and Organization, this issue.

Wei S-J., 1997. Gradualism versus big bang: speed and sustainability of reforms. Canadian Journal of Economics 30, 1234-247.

Weingast B. R., 1995. The economic role of political institutions: market-preserving federalism and economic development. Journal of Law, Economics \& Organization 11, 1-31.

Williamson J. (Ed.), 1994. The political economy of economic reform. Washington DC, INSTITUTE for International Economics.

Williamson, O.E., 2000. The New Institutional Economics: taking stock, looking ahead. Journal of Economic Literature 38, 595-613.

Young, H.P., 1996. The economics of convention. Journal of Economic Perspectives 10, 105112.

Young, H.P., 1998. Individual strategy and social structure; an evolutionary theory of institutions. Princeton, NJ: Princeton University Press.

Zelner B. A., Henisz, W. J., 2009. Contentious implementation and retrenchment in neoliberal policy reform: The global electric power industry 1989-2001. Administrative Science Quarterly 54, 379-412.

JEBO 2693

Eric Brousseau, Pierre Garrouste, Emmanuel Raynaud, Institutional Changes: 
Alternative Theories and Consequences for Institutional Design

Research Highlights

- Institutional a na lysis should rely upon a common framework to explain both the persistence and evolution of institutions

- Assuming perfect rationality do not allow the endogeneization of institutional change

- Assumptions about the endogeneity of the formation of preferences are key to the conceptualization of the nature of institutions

- The drivers of institutional selection and the notion of effic iency rema in controversial

- Institutions a s rules a re understood as the result of processes of bargaining and of balance of power

- Institutions as beliefs a re understood as the result of alignment a mong expectations, which may erode or be affected by extemal shocks

- Much of the applied literature focuses on short-term evolution of formal institutions

- The applied literature on institutional reforms highlights a central shock therapy vs. inc remental change dilemma. 